\title{
Impact of Microbial Mn Oxidation on the Remobilization of Bioreduced U(IV)
}

\author{
Kelly L. Plathe, ${ }^{\dagger}$ Sung-Woo Lee, ${ }^{\ddagger}$ Bradley M. Tebo, ${ }^{\ddagger}$ John R. Bargar, ${ }^{\S}$ and Rizlan Bernier-Latmani ${ }^{*}{ }^{\dagger}$ \\ ${ }^{\dagger}$ Environmental Microbiology Laboratory, Ecole Polytechnique Federale de Lausanne, Station 6, CH-1015, Lausanne, Switzerland \\ ${ }^{\ddagger}$ Environmental and Biomolecular Systems, Oregon Health and Science University, 20000 NW Walker Road, Beaverton, Oregon \\ 97006, United States \\ ${ }^{\S}$ Stanford Synchrotron Radiation Lightsource, 2575 Sand Hill Road, Menlo Park, California 94025, United States
}

\section{Supporting Information}

ABSTRACT: Effects of Mn redox cycling on the stability of bioreduced $\mathrm{U}(\mathrm{IV})$ are evaluated here. $\mathrm{U}(\mathrm{VI})$ can be biologically reduced to less soluble U(IV) species and the stimulation of biological activity to that end is a salient remediation strategy; however, the stability of these materials in the subsurface environments where they form remains unproven. Manganese oxides are capable of rapidly oxidizing $\mathrm{U}(\mathrm{IV})$ to $\mathrm{U}(\mathrm{VI})$ in mixed batch systems where the two solid phases are in direct contact. However, it is unknown whether the same oxidation would take place in a porous medium. To probe that question, U(IV) immobilized in agarose gels was exposed to conditions allowing biological Mn(II) oxidation (HEPES buffer, $\mathrm{Mn}(\mathrm{II}), 5 \% \mathrm{O}_{2}$ and Bacillus sp. SG-1 spores). Results show the oxidation of U(IV) to U(VI) is due primarily to $\mathrm{O}_{2}$ rather than to $\mathrm{MnO}_{2}$. U(VI) produced is retained within the gel to a greater extent when $\mathrm{Mn}$ oxides are present, suggesting the formation of strong surface complexes. The implication for the long-term stability of $U$ in a bioremediated site is that, in the absence of competing ligands, biological $\mathrm{Mn}(\mathrm{II})$ oxidation may promote the immobilization of $\mathrm{U}(\mathrm{VI})$ produced by the oxidation of U(IV).

\section{INTRODUCTION}

Uranium contamination has become a problem in numerous localities across the globe due to several reasons. Foremost among those are mining and milling operations but other sources, such as the use of $U$ in ammunitions, tank shields as well as its presence in fossil fuels, fertilizers and cement ${ }^{1}$ are notable. A main route for the spread of contamination is the transport of hexavalent uranium via groundwater under oxic conditions. Under those conditions, it often occurs as the $\mathrm{UO}_{2}{ }^{2+}$ cation in soluble complexes with various ligands. ${ }^{2,3}$

Reductive precipitation, where $\mathrm{U}(\mathrm{VI})$ is reduced by direct or indirect microbial processes to $\mathrm{U}(\mathrm{IV})$, is a method of in situ remediation which has shown much promise. ${ }^{4,5}$ This reduction often results in the formation of the stable mineral uraninite, $\mathrm{UO}_{2}$, the most common reduced uranium mineral species and the most desirable product of uranium reduction due to its low solubility. ${ }^{6}$ Until recently it was thought that this was the only phase produced during reductive precipitation; however, several laboratories have reported the formation of another U(IV) species, typically U(IV) molecular complexes bound to biomass, which will be operationally termed monomeric $\mathrm{U}(\mathrm{IV}) .^{7-12}$ It is important, therefore, when looking at $\mathrm{U}(\mathrm{IV})$ stability to study not only uraninite, but also monomeric U(IV), which may be more labile and more readily reoxidized than $\mathrm{UO}_{2}{ }^{13}$

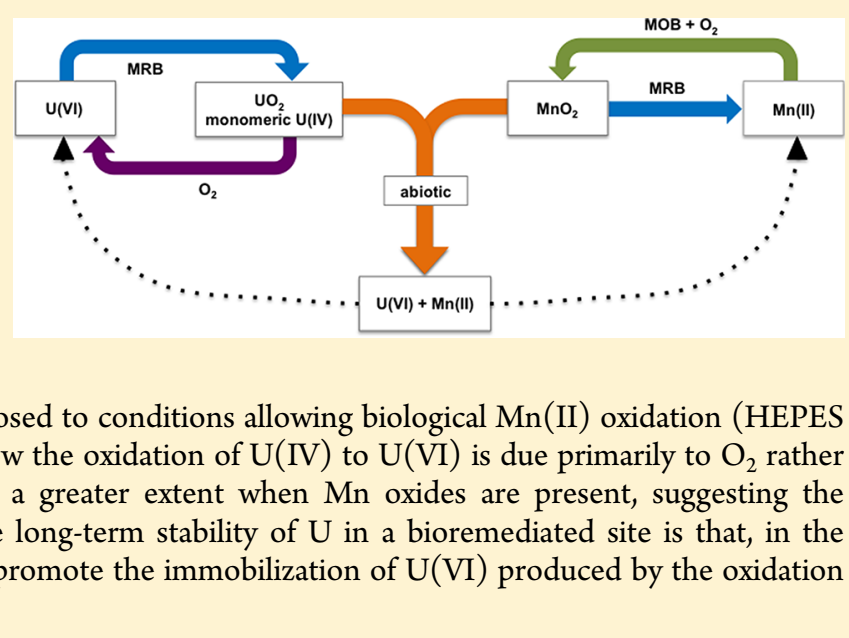

The ultimate success of a remediation effort utilizing uranium bioreduction is dependent on the stability of the final product in the subsurface. $\mathrm{U}(\mathrm{IV})$ species are susceptible to reoxidation by $\mathrm{O}_{2}{ }^{14}$ nitrogen oxides, ${ }^{15} \mathrm{Fe}(\mathrm{III})$ oxides ${ }^{16}$ and $\mathrm{Mn}(\mathrm{IV})$ oxides. ${ }^{17,18} \mathrm{Mn}$ oxides are of particular importance due to the ability of subsurface microorganisms to produce them in situ via $\mathrm{Mn}(\mathrm{II})$ oxidation with $\mathrm{O}_{2} \cdot{ }^{19}$ The presence of $\mathrm{Mn}$ (II)-oxidizing microorganisms, including Bacillus SG-1 spores, is a key component for catalyzing $\mathrm{Mn}$ oxidation, which is otherwise severely kinetically limited. ${ }^{20,21}$ Thus, in the presence of these microorganisms, even in low oxygen environments $\left(5 \% \mathrm{O}_{2}\right)$, $\mathrm{Mn}$ oxides-one of the most powerful natural oxidants in the environment-may form in the vicinity of $U(I V)$ accumulated through bioremediation. Mn oxides have been shown to rapidly oxidize $\mathrm{UO}_{2}$ in well-mixed batch systems at rates considerably faster than $\mathrm{O}_{2}$ alone over varying concentrations $(0-100 \mu \mathrm{M})$ of both $\mathrm{Mn}$ and $\mathrm{U}^{17}$ This oxidation involves the transfer of electrons from one solid phase $\left(\mathrm{MnO}_{2}\right)$ to another $\left(\mathrm{UO}_{2}\right.$ or monomeric $\mathrm{U}(\mathrm{IV})$ ), yielding $\mathrm{Mn}(\mathrm{II})$ and $\mathrm{U}(\mathrm{VI})$. While this process occurs readily in a mixed batch reactor due to extensive solid-solid contact, ${ }^{22}$ it is unknown whether in a porous

Received: September 12, 2012

Revised: February 28, 2013

Accepted: March 13, 2013

Published: March 13, 2013 
medium (such as subsurface sediments) the presence of $\mathrm{MnO}_{2}$ in physical proximity to $\mathrm{U}(\mathrm{IV})$ would be sufficient to transfer electrons.

Additionally, in a system including both $\mathrm{Mn}$ and $\mathrm{U}$, complex redox couplings could take place. Under reducing conditions, like those present during $U$ bioremediation, microbial reduction of $\mathrm{Mn}$ oxides occurs along with reduction of $\mathrm{U}(\mathrm{VI})$, leading to an increased concentration of $\mathrm{Mn}$ (II) in the groundwater. This $\mathrm{Mn}$ (II) could become incorporated into $\mathrm{UO}_{2}$, making it more stable with respect to dissolution. ${ }^{17,18}$ Furthermore, biogenic $\mathrm{Mn}$ oxides have also been shown to be strong sorbents for heavy metal cations ${ }^{23}$ and therefore, have the potential to sorb $\mathrm{U}(\mathrm{VI})$ produced, thereby limiting its transport upon $\mathrm{U}(\mathrm{IV})$ oxidation. It has also been shown that $\mathrm{U}(\mathrm{VI})$ can incorporate structurally into biogenic Mn oxides, ${ }^{24}$ which would also inhibit transport of the contaminant given the stability of the $\mathrm{Mn}$ oxides.

The competing effect of $\mathrm{O}_{2}$ and $\mathrm{MnO}_{2}$ for $\mathrm{U}(\mathrm{IV})$ oxidation as well as the multiple possible fates of $\mathrm{U}(\mathrm{VI})$ in the subsurface are the basis for this investigation. Since this study utilized HEPES buffer as the reaction media, it is important to keep in mind that other ligands (i.e., strong ligands such as carbonate) could alter the results. This study aims at (a) evaluating how biological $\mathrm{Mn}$ (II) oxidation occurring with $\mathrm{O}_{2}$ in a porous medium might affect the stability of $\mathrm{U}\left(\mathrm{IV}\right.$ ) (both $\mathrm{UO}_{2}$ and monomeric $U(I V)$ ) and (b) identifying the ultimate fate of uranium.

\section{MATERIALS AND METHODS}

Gel Puck Preparation. Gel pucks (agarose gels molded to a specific shape and embedded with various components) were used to immobilize U(IV) in a porous matrix and to probe the effect of $\mathrm{Mn}$ (II) oxidation on the radionuclide's speciation and fate. The biogenic $\mathrm{UO}_{2}$ and monomeric U(IV) used in these experiments were synthesized according to Ulrich et al. ${ }^{25}$ and Bernier-Latmani et al. ${ }^{7}$ Bacillus sp. SG-1 spores, which are able to oxidize $\mathrm{Mn}(\mathrm{II})$, were obtained using protocols developed by Francis and Tebo. ${ }^{26}$ Gel pucks were prepared under anoxic conditions by mixing $20 \mathrm{mM}$ HEPES buffer $/ 50 \mathrm{mM} \mathrm{NaCl}$ (Acros Organics, Belgium; pH 7.5), 4\% agarose (Low Melt S; AppliChem, Germany) and the other necessary components $\left( \pm 500 \mu \mathrm{m} U(\mathrm{IV})\right.$ species, $\pm 10^{9}$ spores $\left./ \mathrm{mL}\right)$. Five combinations of the components were prepared: (1) biogenic $\mathrm{UO}_{2}$ with spores, (2) biogenic $\mathrm{UO}_{2}$ without spores, (3) monomeric $\mathrm{U}(\mathrm{IV})$ with spores, (4) monomeric U(IV) without spores, and (5) spores without U. Table 1 includes a complete list of all variations on gel pucks and solutions and the number of replicates for each batch system. These solutions were then poured into syringes and injected into polypropylene tubing (7 $\mathrm{mm}$ ID) to ensure equal dimensions for all pucks. After injection, the tubing was closed at both ends and placed on ice for $15 \mathrm{~min}$ in order to completely polymerize the agarose. Subsequently, the gels were removed from the tubing and cut into pieces approximately $1 \mathrm{~cm}$ long and $7 \mathrm{~mm}$ wide $(V \approx 1.54$ $\left.\mathrm{cm}^{3}\right)$.

U(IV) Oxidation Experiments. Some gel pucks were set aside for digestion and extraction procedures (see next section). The rest of the pucks were placed into $100 \mathrm{~mL}$ serum bottles that contained the $20 \mathrm{mM}$ HEPES/50 $\mathrm{mM} \mathrm{NaCl}$ solution and either $200 \mu \mathrm{M} \mathrm{Mn}^{2+}$ (added as $\mathrm{MnCl}_{2} \cdot 4 \mathrm{H}_{2} \mathrm{O}$, Aldrich, USA) or no $\mathrm{Mn}^{2+}$ to a total volume of $70 \mathrm{~mL}$ (the ratio $\mathrm{U}$ to $\mathrm{Mn}$ in the bottles containing $200 \mu \mathrm{M} \mathrm{Mn(II)} \mathrm{was} \mathrm{5:2).} \mathrm{One} \mathrm{bottle} \mathrm{was}$ also prepared that contained HEPES/NaCl solution, $200 \mu \mathrm{M}$
Table 1. Batch Reactor Conditions ${ }^{a}$

\begin{tabular}{|c|c|c|c|}
\hline & in gel puck & in solution & $\begin{array}{l}\text { no. of } \\
\text { replicates }\end{array}$ \\
\hline 1 & $500 \mu \mathrm{M} \mathrm{UO}{ }_{2} 10^{9}$ spores $/ \mathrm{mL}$ & $200 \mu \mathrm{M} \mathrm{Mn}(\mathrm{II})$ & 9 \\
\hline 2 & $\begin{array}{l}500 \mu \mathrm{M} \text { monomeric } \mathrm{U}(\mathrm{IV}) 10^{9} \\
\text { spores } / \mathrm{mL}\end{array}$ & $200 \mu \mathrm{M} \mathrm{Mn}(\mathrm{II})$ & 9 \\
\hline 3 & $500 \mu \mathrm{M} \mathrm{UO}_{2}$ & $200 \mu \mathrm{M} \mathrm{Mn}(\mathrm{II})$ & 1 \\
\hline 4 & $500 \mu \mathrm{M}$ monomeric $\mathrm{U}(\mathrm{IV})$ & $200 \mu \mathrm{M} \mathrm{Mn}(\mathrm{II})$ & 1 \\
\hline 5 & $500 \mu \mathrm{M} \mathrm{UO}{ }_{2} 10^{9}$ spores $/ \mathrm{mL}$ & & 4 \\
\hline 6 & $\begin{array}{l}500 \mu \mathrm{M} \text { monomeric } \mathrm{U}(\mathrm{IV}) 10^{9} \\
\text { spores } / \mathrm{mL}\end{array}$ & & 4 \\
\hline 7 & $500 \mu \mathrm{M} \mathrm{UO}_{2}$ & & 1 \\
\hline 8 & $500 \mu \mathrm{M}$ monomeric $\mathrm{U}(\mathrm{IV})$ & & 1 \\
\hline 9 & $10^{9}$ spores $/ \mathrm{mL}$ & $200 \mu \mathrm{M} \mathrm{Mn}(\mathrm{II})$ & 1 \\
\hline 10 & & $\begin{array}{l}10^{9} \text { spores } / \mathrm{mL} 200 \\
\mu \mathrm{M} \mathrm{Mn}(\mathrm{II})\end{array}$ & 1 \\
\hline
\end{tabular}

${ }^{a}$ All reactors included $5 \% \mathrm{O}_{2}$ headspace and $50 \mathrm{mM} \mathrm{NaCl}$ and $20 \mathrm{mM}$ HEPES buffer at $\mathrm{pH} 7.5$.

$\mathrm{Mn}^{2+}$ and the same amount of spores in solution as in the gel pucks, but no $U$ or agarose gel, in order to assess any effects from embedding in the agarose. The bottles were capped, sealed and the headspace flushed with a 5\% oxygen/95\% nitrogen gas mix for $5 \mathrm{~min}$. Table 1 contains a compilation of all the experimental conditions considered. All solutions used were prepared anoxically and all gel puck preparations (aside from the $15 \mathrm{~min}$ on ice and headspace flushing) were done in a sterile anoxic glovebox (Shel Lab BacBasic). After flushing, the bottles were wrapped in $\mathrm{Al}$ foil to prevent exposure to light, and thereby inhibit growth of phototrophic organisms. Subsamples from the bottles were taken over the course of the 70-day experiment and analyzed for $\mathrm{Mn}(\mathrm{II})$ and $\mathrm{U}(\mathrm{VI})$ in solution. All $\mathrm{Mn}$ and $\mathrm{U}$ in solution is assumed to be $\mathrm{Mn}(\mathrm{II})$ and $\mathrm{U}(\mathrm{VI})$, respectively since the solid phases are immobilized within the gel. This is a valid assumption as both phases of U(IV) and the spores were added to the gel before it solidified and the spores are the only $\mathrm{Mn}$ oxidizing agent available in the system. $\mathrm{Mn}$ (II) will enter the gel, become oxidized by the spores and remain embedded within the gels. Unfiltered samples were analyzed for $\mathrm{Mn}$ (II) using a formaldoxime colorimetric technique (detection limit $=\sim 0.2 \mu \mathrm{M})^{27}$ and for $\mathrm{U}$ using inductively coupled plasma-mass spectrometry (ICP-MS) (detection limit $=\mathrm{ppt}$ range).

Total Digestion and U(VI) Extraction of Gel Pucks. Total digestions and $\mathrm{U}(\mathrm{VI})$ extractions of the gel pucks were carried out at the beginning, middle and end of the experiment to determine total $U$ and $U(V I)$ concentrations within the pucks, respectively. For both procedures the gel pucks were first dried at $70{ }^{\circ} \mathrm{C}$ for 2 days, either in an oven (gels for digestion) or on a heat block in an anoxic chamber (gels for extraction). For digestion (corresponding to total $\mathrm{U}$ ), the dried gels were placed in $5 \mathrm{~mL}$ of $70 \%$ nitric acid for 3 days. In contrast, the extraction (corresponding to $\mathrm{U}(\mathrm{VI})$ ) used $5 \mathrm{~mL} 50 \mathrm{mM}$ bicarbonate over $24 \mathrm{~h}$ to complex $\mathrm{U}(\mathrm{VI})$ present in the dried gels. The $50 \mathrm{mM}$ bicarbonate concentration was chosen for two reasons: 1) higher concentrations of bicarbonate (i.e., 1M) have been shown to not only extract $\mathrm{U}(\mathrm{VI})$, but also monomeric $\left.\mathrm{U}(\mathrm{IV}){ }^{13} 2\right)$ the concentration of bicarbonate is in great excess ( 2 orders of magnitude) of that of uranium. Hence, bicarbonate is available in sufficient concentrations for $\mathrm{U}(\mathrm{VI})$ extraction. After incubation, a sample from each was diluted and measured using inductively coupled plasma-optical emission spectrometry (ICP-OES). 


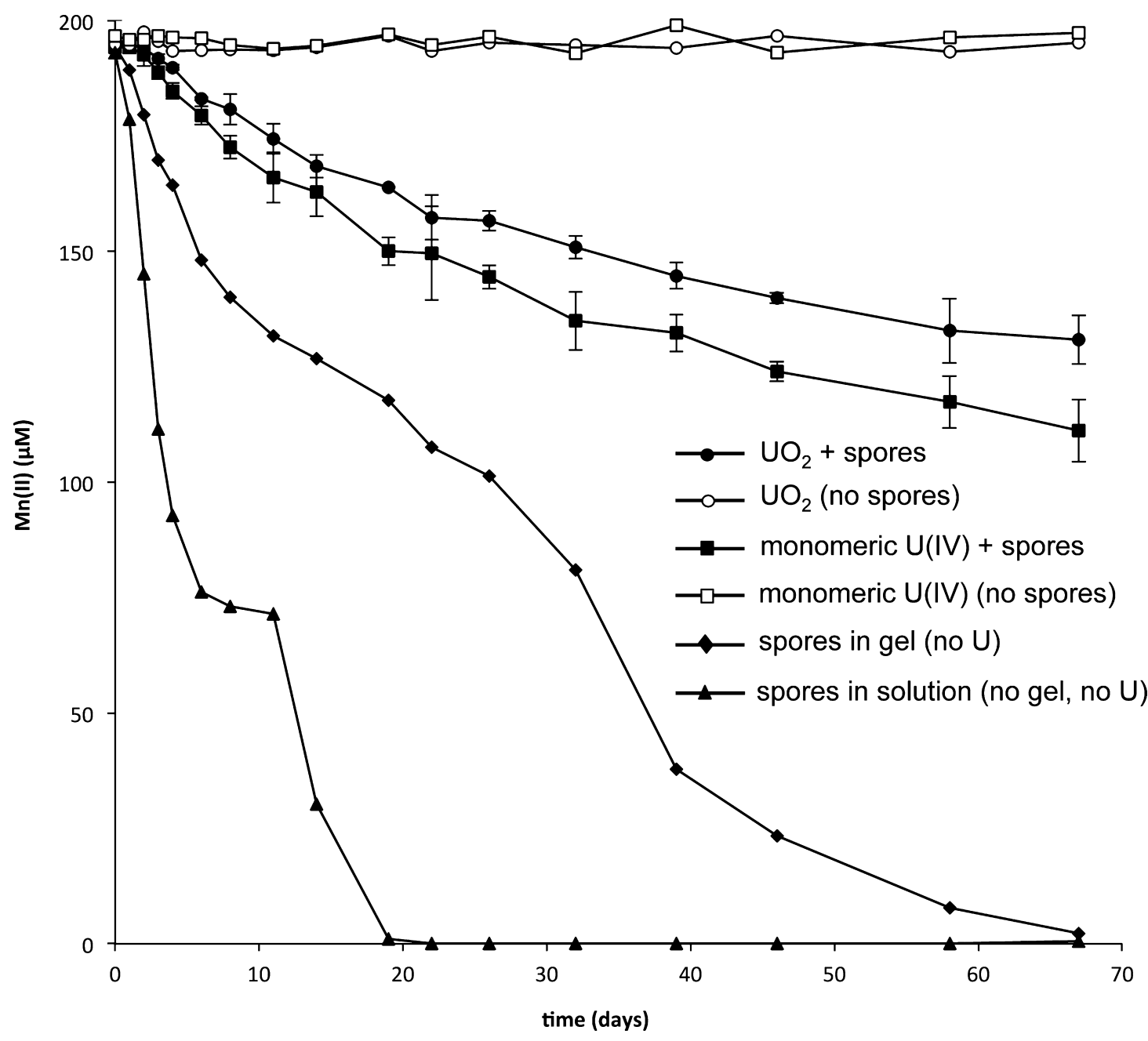

Figure 1. Plot showing Mn concentration in solution over time for all batch reactors that contained $\mathrm{Mn}$ (II). Names in the legend refer to the contents of the gel puck. All solutions contained $200 \mu \mathrm{M} \mathrm{Mn}$ (II) (initial concentration), $20 \mathrm{mM}$ HEPES and $50 \mathrm{mM} \mathrm{NaCl}$ at $\mathrm{pH} 7.5$. Headspace was $5 \% \mathrm{O}_{2}$.

Transmission Electron Microscopy (TEM). At the end of the experiment, two gels (one with biogenic $\mathrm{UO}_{2}$ and one with monomeric $\mathrm{U}(\mathrm{IV})$ ) that had been exposed to $\mathrm{Mn}$ oxidation were prepared for TEM analysis. The pucks were removed from the serum bottles inside a glovebox and dehydrated in incrementally more concentrated ethanol (Fluka) solutions (24 h of $40 \%, 60 \%, 80 \%$, and $100 \%$ ethanol). After dehydration, they were placed in serum bottles containing an acrylic resin (LR white medium grade, SPI Supplies, USA) and incubated at $4{ }^{\circ} \mathrm{C}$ for 1 week to allow the viscous resin to diffuse into the gel. They were then put into a $2 \mathrm{~mL}$ epitube in an oven at $60{ }^{\circ} \mathrm{C}$ overnight to allow the resin polymerization. These small blocks were thin-sectioned using an ultramicrotome (Reichert-Jung, Austria; ULTRACUT), the sections placed on $3 \mathrm{~mm}$ carboncoated 300 mesh Ni grids (SPI Supplies) and imaged with an FEI Tecnai Osiris (FEI, Netherlands) with high resolution and scanning capabilities.

X-ray Absorption Spectroscopy (XAS). Uranium XAS analyses of gel pucks from the beginning and end of the experiment were conducted at beamline 4-1 of the Stanford Synchrotron Radiation Lightsource (SSRL) at the Stanford Linear Accelerator Laboratory (SLAC). The gel pucks were sent to SSRL in sealed serum bottles containing anoxic Milli-Q water (to keep gels from drying) inside a hermetically sealed stainless steel shipping can Schuett-biotec GmbH, Germany) filled with $\mathrm{N}_{2}$ to a slightly positive pressure. Immediately prior to XAS analysis, gels were cut into pieces and mounted in aluminum holders with Lexan windows inside of an anoxic chamber containing 3-4\% $\mathrm{H}_{2}$ and a balance of $\mathrm{N}_{2}$. During analysis, samples were mounted in a cryostat maintained at 77 $\mathrm{K}$ using liquid nitrogen. X-ray absorption near edge structure (XANES) spectra were collected at the $\mathrm{U} \mathrm{L}_{\mathrm{III}}$-edge $(17.2 \mathrm{keV}$ ) in both transmission and fluorescence modes. A double-crystal $\mathrm{Si}$ (220) monochromator was used for energy selection, detuned $\sim 30 \%$ to reject higher harmonic intensities, and was initially calibrated using $\mathrm{Y}$ foil with the first inflection point of the $\mathrm{Y} \mathrm{K}$ edge at $17038.4 \mathrm{eV}$. The $\mathrm{Y}$ foil was also used as an internal calibrant by simultaneously measuring the transmission spectra of the foil and each sample scan. Beamline energy resolution was controlled to be less than the $\mathrm{U} \mathrm{L}_{\mathrm{III}}$-edge line width $(8.67 \mathrm{eV})$ by utilizing vertical slits $(1 \mathrm{~mm})$ in front of the monochromator housing and inside of the experimental hutch. Linear combination fitting (LCF) of the spectra was performed using the Athena program. ${ }^{28}$ Uncertainties are estimated at $\pm 5 \% .{ }^{29}$ The standards used for LCF were U(VI) sorbed onto $\mathrm{Mn}$ oxide and $\mathrm{UO}_{2}$, produced by the same method as for the gel pucks, but chemically extracted to remove biomass. ${ }^{30}$ 


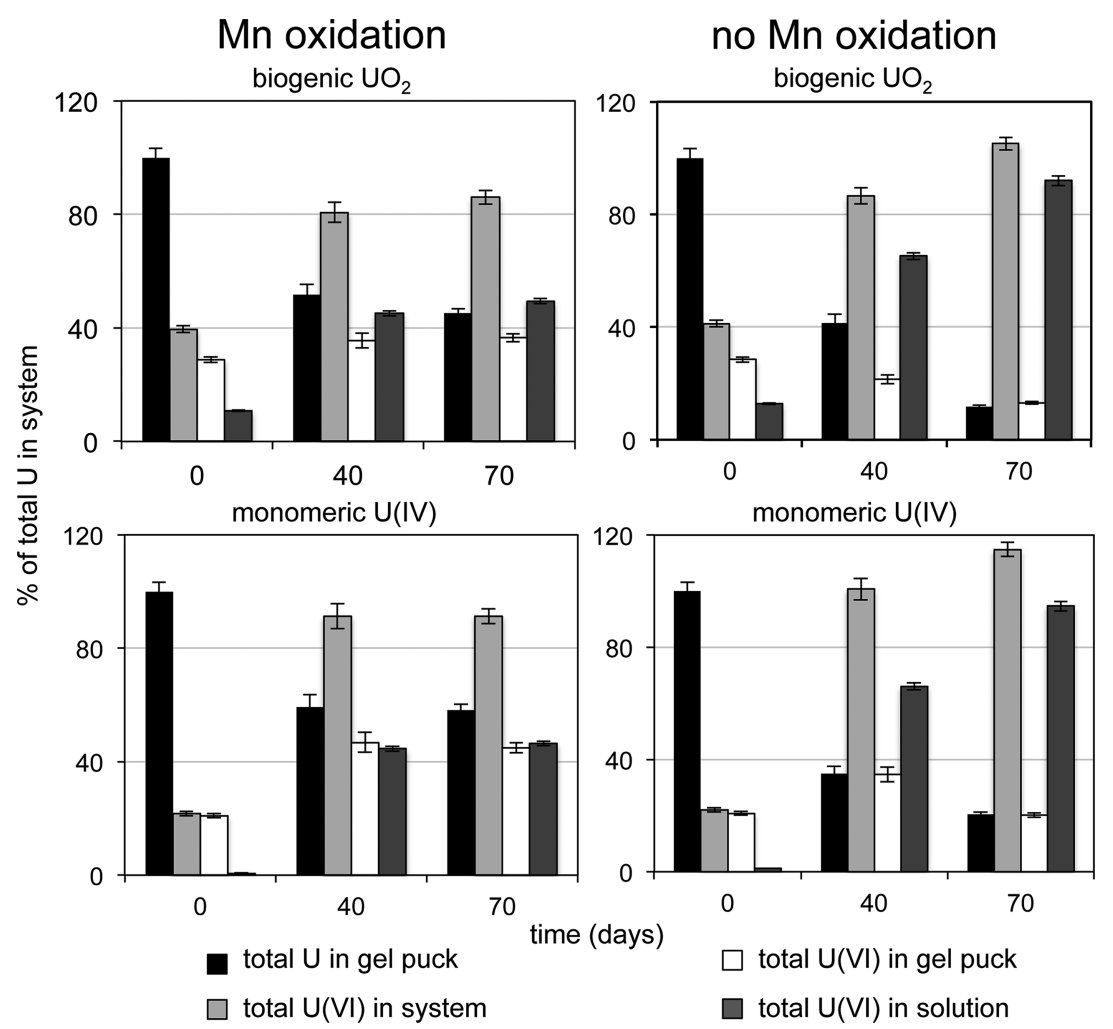

Figure 2. Bar graphs showing the amount of uranium for four different conditions over time. Two conditions represented gel pucks with biogenic $\mathrm{UO}_{2}$ while the other two pucks with monomeric U(IV). Some bottles contained $\mathrm{Mn}$ (II), in which case $\mathrm{Mn}$ (II) oxidation could take place. Total U in gels (black bars) was measured by total digestion and total $\mathrm{U}(\mathrm{VI})$ in gels (white bars) was determined using bicarbonate extraction. Total U(IV) (light gray bars) is the sum of $\mathrm{U}(\mathrm{VI})$ in gel and $\mathrm{U}(\mathrm{VI})$ measured in solution (darkest gray bars). Error bars represent analytical error.

Micro X-ray Absorption Spectroscopy ( $\mu$ XAS). Uranium and manganese $\mu \mathrm{XAS}$ analyses of gel pucks from the end of the experiment were conducted at beamline X05LA of the Swiss Light Source (SLS) at the Paul Scherrer Institute in Villigen, Switzerland. Prior to analysis the gel pucks were dried at $70^{\circ} \mathrm{C}$ in an anoxic environment, broken into pieces and mounted in resin (Epotek 301). Glass-mounted thin-sections of the resin blocks were obtained (Spectrum Petrographics, Inc.). Thinsections and reference materials (monomeric U(IV) and uranyl acetate) were transported to the SLS in the same shipping cans mentioned previously and once there, stored in an anoxic environment. A microfocused beam $\left(\sim 2 \times 2 \mu \mathrm{m}^{2}\right)$ with a 32 element solid-state detector was utilized. Multiple $\mu$ XANES scans were recorded for each region of interest and all samples were analyzed at room temperature.

\section{RESULTS AND DISCUSSION}

Mn and $\mathrm{U}$ Wet Chemical Data. Mn(II) concentration in solution was measured over time for approximately 70 days for all batch reactors (Figure 1). In the cases where spores were absent in the gel puck, $\mathrm{Mn}$ (II) concentration remained constant over the experimental time period. This is due to the fact that no $\mathrm{Mn}$ oxides were produced and $\mathrm{Mn}$ (II) remained in solution. When spores were present, the $\mathrm{Mn}$ (II) concentration decreased by $34-100 \%$ over the given time, indicating the production of Mn oxides by Bacillus sp. SG-1 spores. In the case where uranium was absent, Mn oxidation occurred more rapidly than in the presence of a uranium species. This increased reaction rate could be due an inhibitory effect of uranium on spores. ${ }^{17}$ It could also be an indication that redox cycling is occurring: Mn oxides produced by the spores are reduced by oxidizing $\mathrm{U}(\mathrm{IV})$ and release $\mathrm{Mn}(\mathrm{II})$, leading to a slower decrease in the bulk $\mathrm{Mn}$ (II) concentration. In the case where there is no agarose, just spores in solution, Mn oxidation reaction is much faster than all other cases due to the absence of agarose-induced diffusive limitations.

To determine whether the presence of freshly produced biogenic $\mathrm{Mn}$ oxides had an effect on the reduced uranium species present within the gel puck we probed the concentration of total uranium and $\mathrm{U}(\mathrm{VI})$ in the gel puck and in solution over time in incubations with $5 \% \mathrm{O}_{2}$ with or without a $\mathrm{Mn}(\mathrm{II})$ amendment (Figure 2). A notable initial contribution of $\mathrm{U}(\mathrm{VI})$ is discernible (Figure 2) and this is due to the need for briefly exposing the gel pucks to $\mathrm{O}_{2}$ during the polymerization step. The results clearly show that total $U$ in the gel decreases over time in all cases considered. However, the cases that received $\mathrm{Mn}(\mathrm{II})$ display less total $\mathrm{U}$ loss from the gel than the cases that only received $\mathrm{O}_{2}$. The difference between these two conditions ( $\mathrm{Mn}$ oxidation and no $\mathrm{Mn}$ oxidation) is statistically significant $(p<0.001)$ for both biogenic $\mathrm{UO}_{2}$ and monomeric U(IV). Nonetheless, and in contrast to total $U$, total $\mathrm{U}(\mathrm{VI})$ in the bottles was approximately equivalent or slightly increased in the case where no Mn oxidation took place (Figure 2). This suggests that the presence of $\mathrm{Mn}(\mathrm{II})$ and subsequent formation of biogenic $\mathrm{Mn}$ oxides does not significantly alter the rate of $\mathrm{U}(\mathrm{IV})$ oxidation by $\mathrm{O}_{2}$. This is in contrast to the findings of increased rates of oxidation of $\mathrm{UO}_{2}$ in mixed batch systems where $\mathrm{Mn}(\mathrm{II})$ oxidation was extant. ${ }^{17}$ This difference can be explained by the need for direct contact between the solid phase oxidant and solid phase reductant. $^{22}$ This contact is more difficult to achieve in a porous 


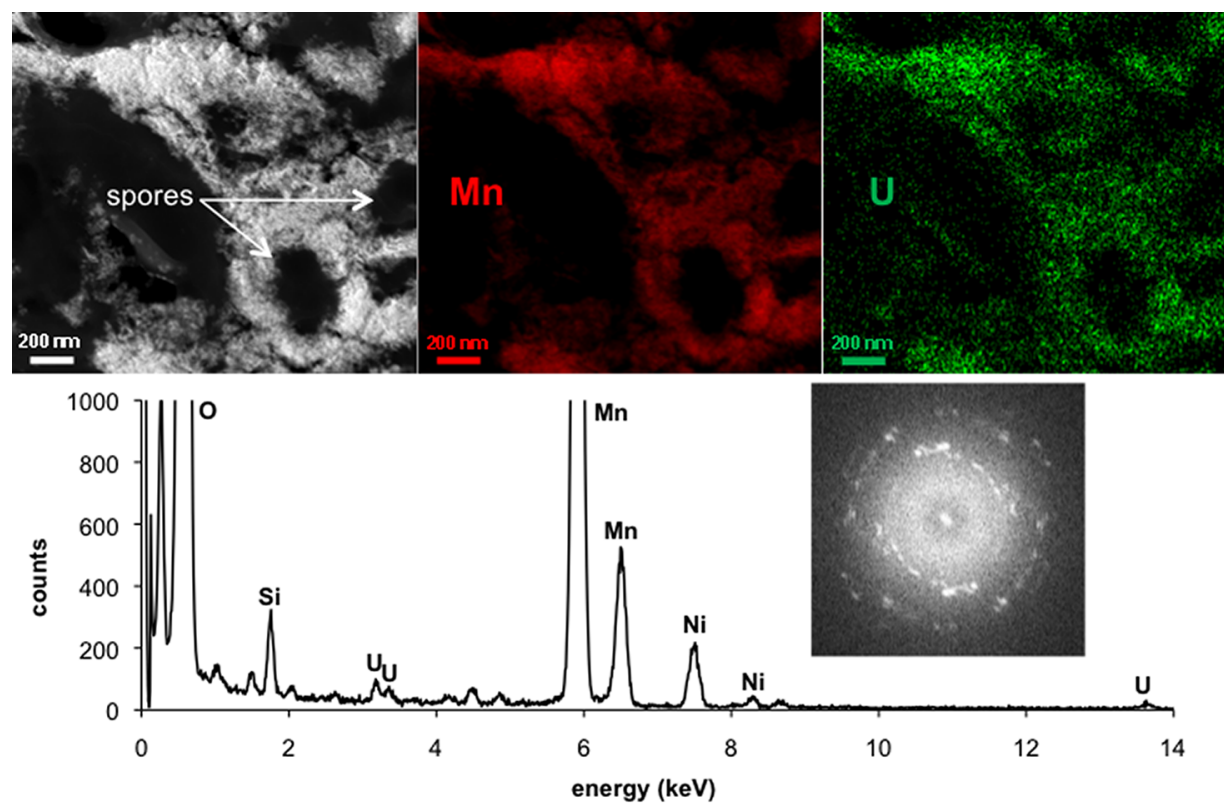

Figure 3. Image on top left is a HAADF (high angle annular dark field) image that is typical of the sample. Spores are present as black masses while the surrounding white material is $\mathrm{Mn}$ oxides. The two images to the right are $\mathrm{Mn}$ and $\mathrm{U}$ chemical maps obtained using EDS. A chemical spectrum of the $\mathrm{Mn}$ oxides is given on the bottom along with an inset showing the FFT of a high-resolution image of the oxides.

medium in which the two solids are immobilized than in a fully mixed batch system.

Total $\mathrm{U}(\mathrm{VI})$ in the bottle was further broken down into $\mathrm{U}(\mathrm{VI})$ remaining in the gel and $\mathrm{U}(\mathrm{VI})$ in solution. There was a major difference between gels in which $\mathrm{Mn}$ (II) oxidation took place and those in which only $\mathrm{O}_{2}$ was present. In the former, $\mathrm{U}(\mathrm{VI})$ was retained in the gel to a much greater extent than in the latter. There is less $\mathrm{U}(\mathrm{VI})$ in solution and more $\mathrm{U}(\mathrm{VI})$ in the gel where $\mathrm{Mn}$ oxides were formed than in their absence. This is attributable to the fact that $\mathrm{Mn}$ oxides formed via biological $\mathrm{Mn}(\mathrm{II})$ oxidation act as excellent sorbents for $\mathrm{U}(\mathrm{VI}){ }^{24,31}$ The overall picture that emerges from this experiment is that biological $\mathrm{Mn}(\mathrm{II})$ oxidation does not impact the rate of $\mathrm{U}(\mathrm{IV})$ oxidation in porous media due to the lack of immediate physical proximity between solid phase U(IV) and $\mathrm{Mn}(\mathrm{IV})$. Hence, $\mathrm{O}_{2}$ can remain a dominant oxidant over $\mathrm{Mn}$ oxides in oxygenated groundwater. Furthermore, the presence of biogenic $\mathrm{Mn}$ oxides accumulated as a result of microbial $\mathrm{Mn}(\mathrm{II})$ oxidation plays an important role in retaining $\mathrm{U}(\mathrm{VI})$ and preventing its mobilization. If sufficient concentrations of bicarbonate are present this may not be the case as bicarbonate is a strong complexant for $\mathrm{U}(\mathrm{VI})$ and could cause it to be mobilized.

Transmission Electron Microscopy. TEM was conducted in order to probe the association between $\mathrm{Mn}$ and $\mathrm{U}$ after $\mathrm{Mn}$ (II) oxidation. In order to achieve this goal, images, chemical spectra, and chemical maps were obtained for the gel pucks containing spores and either biogenic $\mathrm{UO}_{2}$ or monomeric U(IV) at day 70 of the experiment. As the TEM data are similar regardless of the type of reduced uranium present within the gel pucks, only data from the gel puck initially containing $\mathrm{UO}_{2}$ are shown here (Figure 3).

As previously observed, $\mathrm{Mn}$ oxides produced by the spores were nanoparticulate in size $(\sim 3 \times 25 \mathrm{~nm})$ and lathlike in shape (Supporting Information Figure S1). ${ }^{26,32,33}$ The oxides are also polycrystalline as proven by the appearance of distinct rings in the Fast Fourier Transform (FFT) of high-resolution images (inset in bottom in Figure 3). Chemical maps (energy dispersive X-ray spectroscopy, EDS) of the localization of Mn and $U$ in the same area as an HAADF image (high angle annular dark field) show the colocalization of the two elements. A chemical spectrum typical of the sample shows that $\mathrm{Mn}$ is the main element and that uranium is present at a much smaller concentration. Even after extensive observation of the samples, no particulate uranium was found (i.e., in the form of $\mathrm{UO}_{2}$ ). This is not surprising if one considers the relative concentrations of the two species in the gel puck. For example, in the $\mathrm{UO}_{2}$ gel puck at day 70 , there was $0.79 \mu$ moles of $\mathrm{UO}_{2}$ and about $69 \mu$ moles of $\mathrm{Mn}$ oxide, a difference of almost 2 orders of magnitude. Because of the quantitative dominance of $\mathrm{Mn}$ in the gel puck, it is likely to obscure nanoparticles of $\mathrm{UO}_{2}$ or tufts of monomeric U(IV). It is also highly probable that $\mathrm{U}(\mathrm{VI})$ is absorbed to the surface of these Mn oxides since the chemical maps show such correlation over a large area and because, as was previously stated, $\mathrm{Mn}$ oxides are known sorbents for U(VI).

X-ray Absorption Spectroscopy. To determine how much of the original reduced uranium in the gel pucks had been oxidized to $\mathrm{U}(\mathrm{VI})$ over the course of the experiment, bulk $\mathrm{U}$ $\mathrm{L}_{\mathrm{III}}$-edge X-ray absorption near edge spectroscopy (XANES) spectra were measured for gel pucks which contained spores, and either biogenic $\mathrm{UO}_{2}$ or monomeric $\mathrm{U}(\mathrm{IV})$, both before and during $\mathrm{Mn}$ oxidation (day 0 and day 40). Spectra for these four samples and for two standards (biogenic $\mathrm{UO}_{2}$ and $\mathrm{U}(\mathrm{VI})$ sorbed on $\mathrm{MnO}_{2}$ ) are presented in Figure 4.

Spectra for the two gel pucks from day 0 generally resemble that of the U(IV) standard (Figure 4), although a slight shift to higher energy indicates that some U(VI) is present, even in the initial gel pucks. This result indicates that prior to incubation with $\mathrm{Mn}$ (II), uranium is present mostly as U(IV) in the gel pucks. At day 40, the spectra for the sample gels show that the peaks have shifted appreciably toward the U(VI) standard, implying oxidation of $\mathrm{UO}_{2}$ and monomeric $\mathrm{U}(\mathrm{IV})$. Another indication of the increased concentration of $\mathrm{U}(\mathrm{VI})$ in these day 


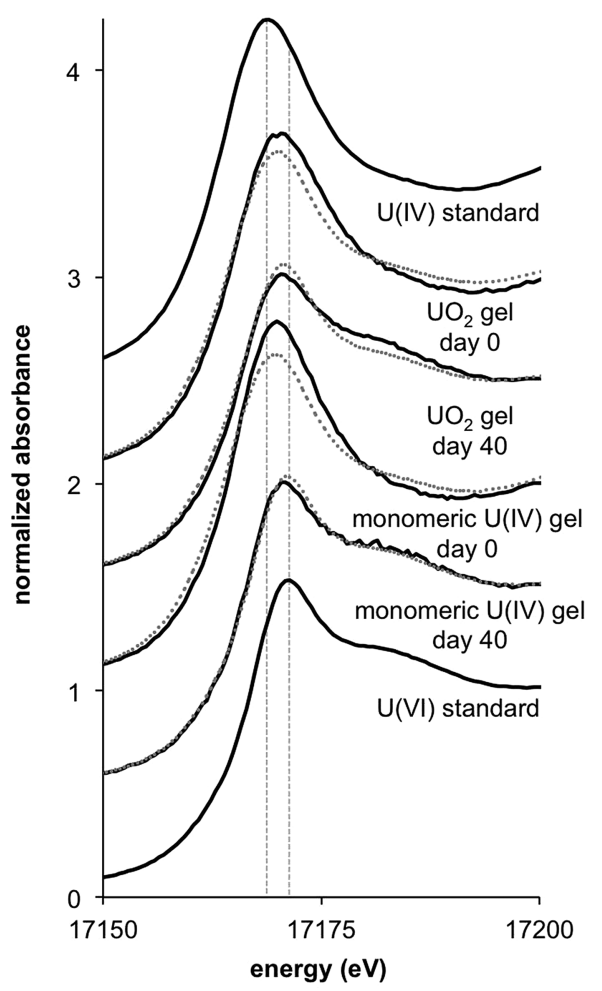

Figure 4. Bulk $\mathrm{U} \mathrm{L}_{\mathrm{III}}$-edge XANES spectra for 2 types of gel pucks (biogenic $\mathrm{UO}_{2}$ and monomeric $\mathrm{U}(\mathrm{IV})$ both before and during $\mathrm{Mn}$ oxidation (day 0 and day 40, respectively) and two standards (biogenic $\mathrm{UO}_{2}$ and $\mathrm{U}(\mathrm{VI})$ sorbed on $\mathrm{MnO}_{2}$ ). Vertical dashed lines represent locations of the peak maxima for the standards and the dashed spectra are linear combination fits for each sample.

40 pucks is the presence of a distinct shoulder on the righthand side of the peaks (starting at ca $17180 \mathrm{eV}$ ). This feature is characteristic of uranyl transdioxo multiple scattering ${ }^{34}$ and can be seen here in the U(VI) standard spectrum.

Linear combination fitting was performed on both sets of gel puck samples (day 0 and day 40) with $\mathrm{U}(\mathrm{IV}$ ) and $\mathrm{U}(\mathrm{VI})$ standards in order to quantify the contribution of each oxidation state in the gel samples (Table 2). From these data, it is apparent that there has been extensive uranium oxidation in the gel puck over the course of the experiment. The gel containing biogenic $\mathrm{UO}_{2}$ initially had only $35 \%$ of the uranium

Table 2. Results of Extraction and Digestion of Gels for $U$ Concentrations and Linear Combination Fittings of Samples from Both Bulk XANES and $\mu$ XANES Analyses with a U(IV) and a U(VI) Standard ${ }^{a}$

\begin{tabular}{lll} 
method of analysis & \multicolumn{1}{c}{ type of gel puck } & $\% \mathrm{U}(\mathrm{VI})$ \\
extraction/digestion & $\mathrm{UO}_{2}$ day 0 & $32( \pm 1.3)$ \\
& $\mathrm{UO}_{2}$ day 40 & $68( \pm 1.4)$ \\
monomeric U(IV) day 0 & $21( \pm 0.8)$ \\
& monomeric U(IV) day 40 & $79( \pm 7.8)$ \\
\multirow{3}{*}{ Bulk XANES } & $\mathrm{UO}_{2}$ day 0 & 35 \\
& $\mathrm{UO}_{2}$ day 40 & 68 \\
& monomeric U(IV) day 0 & 26 \\
$\mu-$ XANES & monomeric U(IV) day 40 & 91 \\
& particle 1 & 77 \\
& Particle 2 & 38
\end{tabular}

${ }^{a}$ Uncertainties for XANES analyses are estimated to be $\pm 5 \%{ }^{29}$ as $\mathrm{U}(\mathrm{VI})$ at day 0 and after 40 days this contribution increased to $67 \%$ despite the loss of some U(VI) to solution. The gel containing monomeric U(IV) increased even more drastically, from $26 \%$ to $90 \%$. The more dramatic increase in oxidation of the monomeric U(IV) could possibly be due to the fact that, unlike the mineral $\mathrm{UO}_{2}$, it is amorphous and likely more easily oxidized. ${ }^{13}$ The XAS LCF data and the extraction data are summarized in Table 2 display remarkable agreement. For instance, for $\mathrm{UO}_{2}$ after 40 days, both methods indicate that $\mathrm{U}(\mathrm{VI})$ represents $68 \%$ of the total $\mathrm{U}$.

Along with bulk XAS, samples were prepared for micro-XAS analysis ( $\mu \mathrm{XAS}) . \mu \mathrm{XAS}$ allows sample visualization and concomitant chemical mapping of areas of interest. This was done in order to localize $\mathrm{Mn}$ and $\mathrm{U}$ with respect to one another. Chemical maps of two particles from the monomeric U(IV) gel puck (post Mn oxidation) can be seen in Figure 5. These two particles were chosen for analysis because initial probing showed the larger particle to be mostly Mn, while the smaller particle was almost entirely composed of U. Since the $\mathrm{Mn}$ oxides produced by the spores are nanoparticulate in size and "particle 1" is much larger than this $(\sim 2 \mu \mathrm{m})$, it is thought that this particle corresponds to a cluster or aggregate of $\mathrm{Mn}$ oxides particles. Because of the high-density of $\mathrm{Mn}$ oxides present in the gel puck (Figure 3 ) this is a likely conclusion. It was thought that $U$ surrounding the larger particle would be oxidized because of its association with Mn oxides, while the smaller particle would be mostly U(IV). To determine this quantitatively, $\mathrm{U} \mathrm{L}_{\mathrm{III}}$-edge $\mu$ XANES analyses were done for both particles in U-rich areas (location of $\mu$ XANES is indicated by blue dots on particles in Figure 5). Results of these analyses can be seen in Figure 5. Based on qualitative inspection of the spectra, uranium associated with particle 1 is more oxidized than that in particle 2 . LCF confirmed this observation as only $21 \%$ of total uranium in particle 1 was U(IV), while $62 \%$ of the total uranium in particle 2 was shown to be U(IV) (Table 2). These chemical maps also support the notion that $\mathrm{U}(\mathrm{VI})$ may be adsorbing to Mn oxide surfaces.

Environmental Implications. Overall, the combination of techniques used in this study allowed elucidation of several key points in the $\mathrm{Mn}-\mathrm{U}$ redox system. First, these results indicate that the substantial oxidation of U(IV) observed is attributable to $\mathrm{O}_{2}$, rather than $\mathrm{MnO}_{2}$. Second, $\mathrm{Mn}$ oxides have a stabilizing effect on $\mathrm{U}(\mathrm{VI})$ produced by oxidation as more $\mathrm{U}(\mathrm{VI})$ was lost into solution from the gel in which no Mn oxides were present. $\mathrm{U}(\mathrm{VI})$ remaining within the gel is likely sorbed to or associated with the surface of the oxides as visualized by a halo of $\mathrm{U}(\mathrm{VI})$ surrounding the oxide particles within the gel pucks (Figure 5). If there are systems where there is a significant amount of bicarbonate in the groundwater, however, $\mathrm{U}(\mathrm{VI})$ will likely be mobilized as bicarbonate forms strong complexes with U(VI).

These results shed light on an aspect of uranium bioremediation that was thus far little understood. Biological $\mathrm{Mn}$ oxidation is known to be ubiquitous in the environment ${ }^{32}$ and the oxidation of soluble $\mathrm{Mn}$ (II) is autocatalytic and only requires very low partial pressures of oxygen to take place. ${ }^{35}$ Based on those facts and the results of this work, we hypothesize that the formation of $\mathrm{Mn}$ oxides in bioremediated areas will have mostly a mitigating effect by immobilizing $\mathrm{U}(\mathrm{VI})$ produced by $\mathrm{O}_{2}$-driven $\mathrm{U}(\mathrm{IV})$ oxidation. Therefore, the presence of $\mathrm{Mn}$ oxides may well prevent or retard the downstream mobilization of $\mathrm{U}(\mathrm{VI})$. 

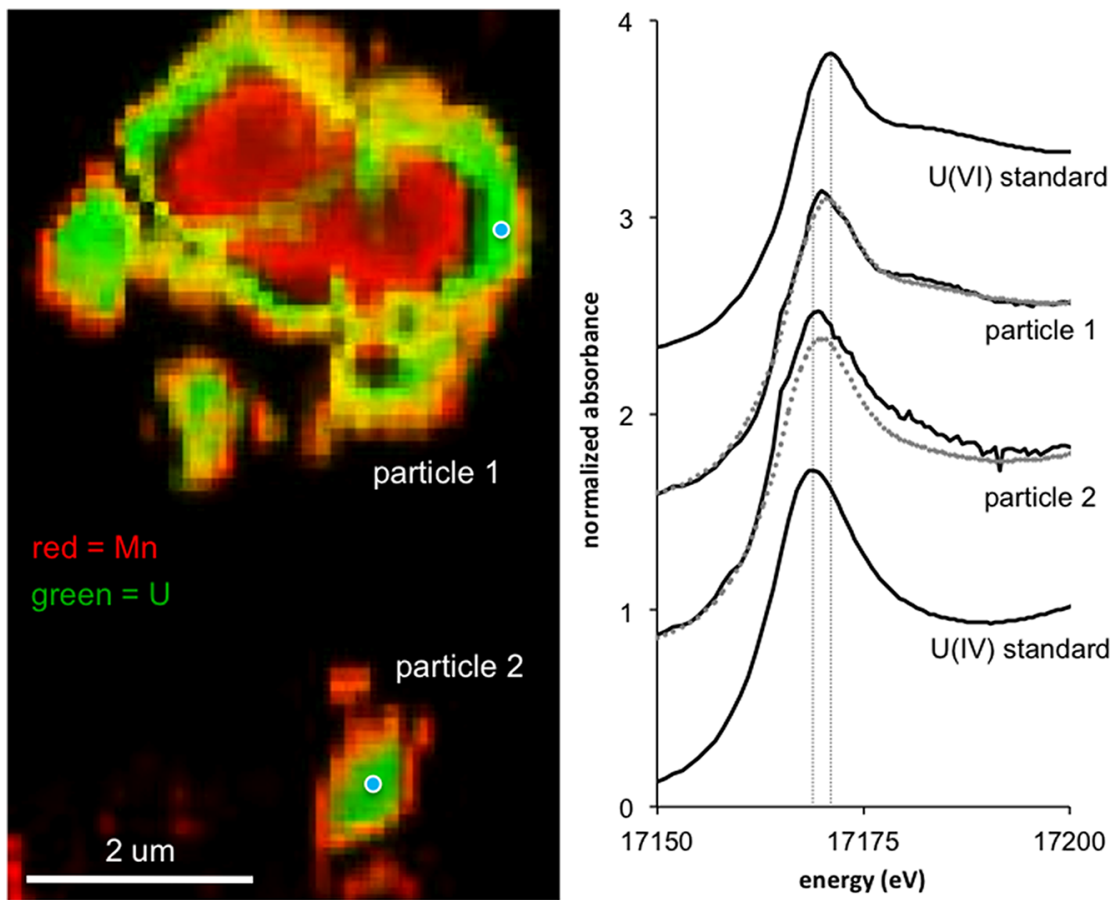

Figure 5. Left image shows chemical maps of $\mathrm{Mn}$ (green) and $\mathrm{U}$ (red) for two particles from a gel puck containing monomeric U(IV) and spores after Mn oxidation took place. Yellow areas indicate $\mathrm{Mn}$ and $\mathrm{U}$ overlap. Graph on right is the $\mu \mathrm{XAS} \mathrm{U} \mathrm{L}_{\mathrm{III}}$-edge XANES data for certain areas of the two particles on the right (areas indicated by the blue dots on the particles) and for two standards (monomeric U(IV) and uranyl acetate). Vertical dashed lines represent locations of the peak maxima for the standards and the dashed spectra are the linear combination fits for each particle spectrum.

\section{ASSOCIATED CONTENT}

\section{S Supporting Information}

Figure S1. (a) BF TEM (bright-field TEM) image of selected area of a gel puck containing biogenic $\mathrm{UO}_{2}$, spores and $\mathrm{Mn}$ oxides; (b) low magnification BF image; (c) high-resolution TEM image showing lattice spacings, indicative of crystallinity of the sample. This material is available free of charge via the Internet at http://pubs.acs.org.

\section{AUTHOR INFORMATION}

\section{Corresponding Author}

*Phone: +41 21693 5001; e-mail: rizlan.bernier-latmani@epfl. ch.

\section{Notes}

The authors declare no competing financial interest.

\section{ACKNOWLEDGMENTS}

This work was funded by a grant from the US-DOE Subsurface Biogeochemical Research program to OHSU (Grant No. DEOSC0005324). Portions of this research were carried out at the Stanford Synchrotron Radiation Lightsource, a Directorate of SLAC National Accelerator Laboratory and an Office of Science User Facility operated for the U.S. Department of Energy Office of Science by Stanford University. The SSRL Structural Molecular Biology Program is supported by the DOE Office of Biological and Environmental Research, and by the National Institutes of Health, National Institute of General Medical Sciences (including P41GM103393) and the National Center for Research Resources (P41RR001209). The contents of this publication are solely the responsibility of the authors and do not necessarily represent the official views of NIGMS, NCRR or NIH. The $\mu$ XAS data were collected on the
MicroXAS (X05LA) beamline at the Swiss Light Source, Paul Scherrer Institut, Villigen, Switzerland. We are grateful to Daniel Grolimund and Camelia Borca at the Swiss Light Source whose outstanding efforts have made these measurements possible and we acknowledge their help with data analysis. We would also like to thank Daniel Alessi for help with running the samples and Marco Cantoni for support with EDX mapping data collection. We also thank Daniel Giammar, for helpful discussions.

\section{REFERENCES}

(1) Linking Legacies: Connecting the Cold War Nuclear Weapons Processes to Their Environmental Consequences, DOE/EM-0319; U.S. Department of Energy: Washington, DC, 1997.

(2) Arnold, T.; Utsonomiya, S.; Geipel, G.; Ewing, R. C.; Baumann, N.; Brendler, V. Adsorbed U(VI) surface species on muscovite identified by laser fluorescence spectroscopy and transmission electron spectroscopy. Environ. Sci. Technol. 2006, 40, 4646-4652.

(3) Langmuir, D. Aqueous Environmental Chemistry; Prentice Hall: Upper Saddle River, NJ, 1997.

(4) Lovley, D. R.; Phillips, E. J. P.; Gorby, Y.; Landa, E. R. Microbial reduction of uranium. Nature 1991, 350, 413-416.

(5) Jeon, B.-H.; Dempsey, B. A.; Burgos, W. D.; Barnett, M. O.; Roden, E. E. Chemical reduction of U(VI) by $\mathrm{Fe}(\mathrm{II})$ at the solid-water interface using natural and synthetic Fe(III) oxides. Environ. Sci. Technol. 2005, 39, 5642-5649.

(6) Langmuir, D. Uranium solution-mineral equilibria at low temperatures with applications to sedimentary ore deposits. Geochim. Cosmochim. Acta 1978, 42, 547-569.

(7) Bernier-Latmani, R.; Veeramani, H.; Vecchia, E. D.; Junier, P.; Lezama-Pacheco, J. S.; Suvorova, E. I.; Sharp, J. O.; Wigginton, N. S.; Bargar, J. R. Non-uraninite products of microbial U(VI) reduction. Environ. Sci. Technol. 2010, 44 (24), 9456-9462.

(8) Boyanov, M. I.; Fletcher, K. E.; Kwon, M. J.; Rui, X.; O’Loughlin, E. J.; Loeffler, F. E.; Kemner, K. M. Solution and microbial controls on 
the formation of reduced U(IV) species. Environ. Sci. Technol. 2011, 45 (19), 8336-8344.

(9) Campbell, K. M.; Davis, J. A.; Bargar, J.; Giammar, D.; BernierLatmani, R.; Kukkadapu, R.; Williams, K. H.; Veramani, H.; Ulrich, K. U.; Stubbs, J.; Yabusaki, S.; Figueroa, L.; Lesher, E.; Wilkins, M. J.; Peacock, A.; Long, P. E. Composition, stability, and measurement of reduced uranium phases for groundwater bioremediation at Old Rifle, CO. Appl. Geochem. 2011, 26, S167-S169.

(10) Fletcher, K. E.; Boyanov, M. I.; Thomas, S. H.; Wu, Q.; Kemner, K. M.; Loeffler, F. E. U(VI) reduction to mononuclear U(IV) by desulfitobacterium species. Environ. Sci. Technol. 2010, 44 (12), 47054709.

(11) Sharp, J. O.; Lezama-Pacheco, J. S.; Schofield, E. J.; Junier, P.; Ulrich, K.-U.; Chinni, S.; Veeramani, H.; Margot-Roquier, C.; Webb, S. M.; Tebo, B. M.; Giammar, D. E.; Bargar, J. R.; Bernier-Latmani, R. Uranium speciation and stability after reductive immobilization in aquifer sediments. Geochim. Cosmochim. Acta 2011, 75 (21), 64976510.

(12) Veeramani, H.; Alessi, D. S.; Suvorova, E. I.; Lezama-Pacheco, J. S.; Stubbs, J. E.; Sharp, J. O.; Dippon, U.; Kappler, A.; Bargar, J. R.; Bernier-Latmani, R. Products of abiotic U(VI) reduction by biogenic magnetite and vivianite. Geochim. Cosmochim. Acta 2010, 75 (9), 2512-2528.

(13) Alessi, D. S.; Uster, B.; Veeramani, H.; Suvorova, E. I.; LezamaPacheco, J. S.; Stubbs, J. E.; Bargar, J. R.; Bernier-Latmani, R. Quantitative separation of monomeric U(IV) from $\mathrm{UO}_{2}$ in products of U(VI) reduction. Environ. Sci. Technol. 2012, 46 (11), 6150-6157.

(14) Ulrich, K. U.; Ilton, E. S.; Veeramani, H.; Sharp, J. O.; BernierLatmani, R.; Schofield, E. J.; Bargar, J. R.; Giammar, D. E. Comparative dissolution kinetics of biogenic and chemogenic uraninite under oxidizing conditions in the presence of carbonate. Geochim. Cosmochim. Acta 2009, 73 (20), 6065-6083.

(15) Moon, H. S.; Komlos, J.; Jaffe, P. R. Uranium reoxidation in previously bioreduced sediment by dissolved oxygen and nitrate. Environ. Sci. Technol. 2007, 41 (13), 4587-4592.

(16) Ginder-Vogel, M.; Steward, B.; Fendorf, S. Kinetic and mechanistic constraints on the oxidation of biogenic uraninite by ferrihydrite. Environ. Sci. Technol. 2010, 44 (1), 163-169.

(17) Chinni, S.; Anderson, C. R.; Ulrich, K. U.; Giammar, D. E.; Tebo, B. M. Indirect $\mathrm{UO}_{2}$ oxidation by $\mathrm{Mn}$ (II)-oxidizing spores of Bacillus sp strain SG-1 and the effect of $\mathrm{U}$ and $\mathrm{Mn}$ concentrations. Environ. Sci. Technol. 2008, 42 (23), 8709-8714.

(18) Veeramani, H.; Schofield, E. J.; Sharp, J. O.; Suvorova, E. I.; Ulrich, K. U.; Mehta, A.; Giammar, D. E.; Bargar, J. R.; BernierLatmani, R. Effect of $\mathrm{Mn}$ (II) on the structure and reactivity of biogenic uraninite. Environ. Sci. Technol. 2009, 43 (17), 6541-6547.

(19) Wehrli, B.; Friedl, G.; Manceau, A., Reaction rates and products of manganese oxidation at the sediment-water interface. In Aquatic Chemistry: Interfacial and Interspecies Processes; Huang, C. P., O'Melia, C. R., Morgon, J. J., Eds.; American Chemical Society: Washington, DC, 1995; Vol. 244, pp 111-134.

(20) Brezonik, P., Kinetics of Chemical Reactions in Aquatic Systems. In Chemical Kinetics and Process Dynamics in Aquatic Systems; Lewis Publishers, 1993.

(21) Stumm, W.; Morgan, J., Aquatic Chemistry; John Wiley \& Sons, Inc.: New York, NY, 1996.

(22) Wang, Z. M.; Lee, S. W.; Kapoor, P.; Tebo, B. M.; Giammar, D. E. Uraninite oxidation and dissolution induced by manganese oxide: A redox reaction between two insoluble minerals. Geochim. Cosmochim. Acta 2013, 100, 24-40.

(23) Villalobos, M.; Bargar, J.; Sposito, G. Trace metal retention on biogenic manganese oxide nanoparticles. Elements 2005, 1 (4), 223226.

(24) Webb, S. M.; Fuller, C. C.; Tebo, B. M.; Bargar, J. R. Determination of uranyl incorporation into biogenic manganese oxides using X-ray absorption spectroscopy and scattering. Environ. Sci. Technol. 2006, 40 (3), 771-777.

(25) Ulrich, K. U.; Singh, A.; Schofield, E. J.; Bargar, J. R.; Veeramani, H.; Sharp, J. O.; Bernier-Latmani, R.; Giammar, D. E. Dissolution of biogenic and synthetic $\mathrm{UO}_{2}$ under varied reducing conditions. Environ. Sci. Technol. 2008, 42 (15), 5600-5606.

(26) Francis, C.; Tebo, B. M. Manganese (II) oxidation by metabolically dormant spores of diverse Bacillus species. Environ. Microbiol. 2002, 68, 874-880.

(27) Brewer, P.; Spencer, D. Colorimetric determination of manganese in anoxic waters. Limnol. Oceangr. 1971, 16 (1), 107-110.

(28) Ravel, B.; Newville, M. ATHENA, ARTEMIS, HEPHAESTUS: Data analysis for X-ray absorption spectroscopy using IFEFFIT. J. Synchotron. Radiat. 2005, 12 (4), 537-541.

(29) Singer, D. M.; Zachara, J. M.; Brown, G. E., Jr., Uranium speciation as a function of depth in contaminated Hanford sediments-A micro-XRF, micro-XRD, and micro- and bulk-XAFS study. Environ. Sci. Technol. 2009, 43 (3), 630-636.

(30) Schofield, E. J.; Veeramani, H.; Sharp, J. O.; Suvorova, E.; Bernier-Latmani, R.; Mehta, A.; Stahlman, J.; Webb, S. M.; Clark, D. L.; Conradson, S. D.; Ilton, E. S.; Bargar, J. R. Structure of biogenic uraninite produced by Shewanella oneidensis strain MR-1. Environ. Sci. Technol. 2008, 42 (21), 7898-7904.

(31) Manceau, A.; Charlet, L.; Boisset, M. C.; Didier, B.; Spadini, L. Sorption and speciation of heavy metals on hydrous $\mathrm{Fe}$ and $\mathrm{Mn}$ oxides. From microscopic to macroscopic. Appl. Clay Sci. 1992, 7 (1-3), 201-223.

(32) Tebo, B. M.; Bargar, J. R.; Clement, B. G.; Dick, G. J.; Murray, K. J.; Parker, D.; Verity, R.; Webb, S. M. Biogenic manganese oxides: Properties and mechanisms of formation. Annu. Rev. Earth Planet. Sci. 2004, 32, 287-328.

(33) Rosson, R. A.; Nealson, K. H. Manganese binding and oxidation by spores of a marine bacillus. J. Bacteriol. 1982, 151 (2), 1027-1034.

(34) Hudson, E. A.; Allen, P. G.; Terminello, L. J.; Denecke, M. A.; Reich, T. Polarized x-ray-absorption spectroscopy of the uranyl ion: Comparison of experiment and theory. Phys. Rev. B 1996, 54 (1), $156-165$.

(35) Trouwborst, R. E.; Clement, B. G.; Tebo, B. M.; Glazer, B. T.; Luther, G. W. Soluble $\mathrm{Mn}(\mathrm{III})$ in suboxic zones. Science 2006, 313 (5795), 1955-1957. 